\title{
MEŽA EKOSISTËMU ATAINOJUMS LATVIJAS AINAVU GLEZNIECĪBĀ
}

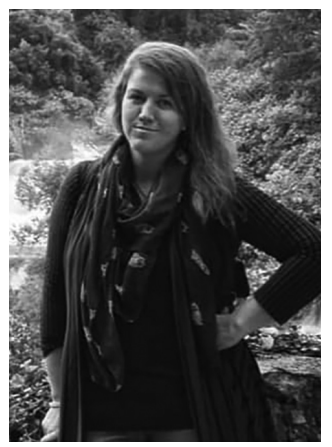

Ilze Pauliṇa ir apguvusi vides dizainu Rēzeknes Mākslas un dizaina vidusskolā un ieguvusi profesionālo bakalaura grādu interjera dizainā Ekonomikas un kultūras augstskolā. Interesējas par mākslu, kultūru un vidi un šo kategoriju savstarpējām kopsakarībām. Patlaban strādā LVMI Silava un piedalās pētījumā Mežsaimniecības ietekme uz meža un saistîto ekosistēmu pakalpojumiem, kurā pēta ekosistēmu kultūras pakalpojumu kategorijas, ko ir sarežgîiti novērtēt ekonomiskā izteiksmē.

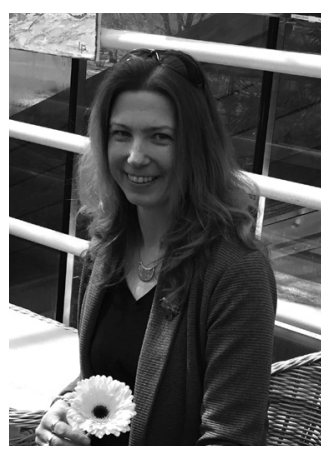

Zane Lībiete pabeigusi Latvijas Lauksaimniecības universitātes Meža fakultāti, 2008. gadā aizstāvējusi promocijas darbu par vienvecuma eg̣̣u tīraudžu augšanas potenciālu. Patlaban studē Latvijas Universitātes Humanitāro zinātnuu fakultātē, Kultūras un sociālās antropoloǵijas maǵistra studiju programmā. LVMI Silava koordinē pêtījumus, kas saistīti ar mežsaimniecības ietekmi uz vielu apriti un ūdens kvalitâti, kā arī ar meža un saistîto ekosistēmu pakalpojumiem kopumā, interesē starpdisciplināra pieeja minētajiem jautājumiem.
Raksturvārdi: meža ekosistēmas, kultūras ekosistēmu pakalpojumi, iedvesma, radošums, ainavu gleznas.

\section{Ievads}

Meži ir daudzfunkcionālas ekosistēmas, kas nodrošina daudzveidīgus ekosistēmu pakalpojumus. Šis daudzpusīgais mērkis ietverts globālā $\overline{1}^{1}$ un nacionālā $\bar{a}^{2}$ regulējumā, nosakot, ka "meža resursi un meža zeme jāapsaimnieko un ilgtspējīgi jāizmanto pašreizējo un nākamo paaudžu sociālo, ekonomisko, ekoloǵisko, kultūras un garīgo vajadzību nodrošināšanai”.

1 ANO 1992.

2 Latvijas Republikas Meža likums 2000.
Dažādie pakalpojumi, ko sniedz meži, iekḷauj nodrošinošos, regulējošos un kultūras pakalpojumus $^{3}$ vai, pēc Vispārējās starptautiskās ekosistēmu pakalpojumu klasifikācijas ${ }^{4}$, nodrošinošos, regulējošos un uzturošos, un kultūras pakalpojumus ${ }^{5}$. Ekosistēmu kultūras pakalpojumi iekḷaujas visās minētajās klasifikācijas sistēmās un veido nozīmīgu un neaizstājamu sastāvdaḷu dabas ieguldījumam cilvēces labklājīibā.

3 Shvidenko et al. 2005; TEEB 2010.

4 Common International Classification of Ecosystem Services (CICES).

5 Haines-Youn, Potschin 2018. 
Tomēr, lai gan ekosistēmu kultūras pakalpojumi tiek atzīti par ḷoti nozīmīgiem cilvēces labklājīibai ${ }^{6}$, par dažām šo pakalpojumu grupām, ieskaitot ekosistēmu sniegto iedvesmu radošām nodarbēm, ir ḷoti maz pieejamās informācijas. Tas lielā mērā saistīts ar grūtībām aprakstìt un kvantitatīvi novērtēt tos ekosistēmu pakalpojumus, kas nesniedz skaidrus materiālus labumus. Kaut gan nav noliedzams, ka dabai ir liela ietekme uz kultūru un ka gan dabiskas, gan apsaimniekotas ekosistēmas iedvesmo plašu kultūras izpausmju spektru, zinātniskā literatūra par šo tēmu ir ḷoti pieticīga.

Tūkstošgades ekosistēmu pakalpojumu novērtējums izšķir piecus galvenos iedvesmas pakalpojumu veidus: verbālā māksla un rakstniecība, ko iedvesmo daba; skatuves māksla; vizuālā māksla; dizains un mode; plašsaziņas mediji kopumā. Daba ir izmantota kā iedvesmas avots daudzos literāros darbos, tā ir ietekmējusi deju, dziesmas un teātri, ir daudz piemēru dažādu ekosistēmu attēlojumam gleznās, skulptūrās un lietišķās mākslas darbos, dabas skaistums plaši izmantots arī ikdienā lietojamos priekšmetos, un dabu plaši izmanto plašsaziņas mediji dažādu programmu veidošanai, kā arī produktu pārdošanai. ${ }^{7}$

Baltijas valstīs uz Ziemelvalstīs mežs ir dominējošā sauszemes ekosistēma, kas lielā mērā ietekmējusi cilvēku labklājību, nodrošinot ar resursiem gan tieši, gan netieši, regulējot klimatu. Tajā pašā laikā daba sniedz daudz vairāk nekā tikai praktiski izmantojamas vērtības un dominējošās ekosistēmas nenoliedzami ir veidojušas arī reǵiona iedzīvotāju kultūras identitāti. Latvijā meži klāj vairāk nekā pusi no valsts platības ${ }^{8}$ un meža ekosistēmas tradicionāli ir bijušas nozīmīgas daudzos aspektos.

Šajā pētījumā esam pievērsušās specifiskai kultūras ekosistēmu pakalpojumu apakškategorijai - iedvesmai mākslinieciskām izpausmēm. Mēs analizējām, kā meža ekosistēmas ir ietekmējušas Latvijā gleznotās ainavas, centāmies identificēt biežāk attēlotās meža ekosistēmas un meklējām sakarības starp gleznām, kurās atainots mežs, un mežainuma izmaiṇām,

6 Millennium Ecosystem Assessment 2005, 155.

7 de Groot et al. 2005.

8 Latvijas Republikas Zemkopības ministrija 2019. un reǵionu raksturojumu, kuros strādājuši mākslinieki.

\section{Materiāls un metode}

Lai novērtētu dažādu meža ekosistēmu tipu un to elementu nozīmi, tika izvērtēti Latvijas mākslinieku darbi, izmantojot divas datu kopas: 1) Latvijas Mākslinieku savienības fondus (kopā 512 gleznas, kas radītas 20. un 21. gadsimtā); 2) tiešsaistē pieejamo informāciju no mākslas izsoḷu namiem (kopā 3131 glezna, kas izsolīta kopš 2005. gada, radīta galvenokārt 20. un 21. gadsimtā, dažas 19. gadsimtā). Mākslas darbu izsoḷu namu mājaslapās ir pieejamas gleznu fotogrāfijas, tāpēc ir iespējams tās vizuāli izvērtēt. Sākotnēji tika definētas desmit kategorijas gleznu klasifikācijai: 1) nav attēlots mežs vai tā elementi; 2) priežu (Pinus sylvestris L.) mežs; 3) egḷu (Picea abies [L.] Karst.) mežs; 4) bērzu (Betula spp.) mežs; 5) jaukts skujkoku mežs; 6) jaukts lapkoku mežs; 7) jaukts mežs; 8) slapjš mežs; 9) mežs ar neidentificējamām koku sugām; 10) meža fragmenti/elementi cita tipa ainavā. Pēc tam kategoriju skaits tika samazināts, lai nodrošinātu pietiekamu meža ainavu reprezentāciju katrā grupā, un tālākā analīzē tika iekḷautas sešas kategorijas: 1) nav attēlots mežs vai tā elementi; 2) skujkoku mežs (priežu, egḷu vai jaukts skujkoku); 3) lapkoku mežs (bērzu un jaukts lapkoku); 4) jaukts mežs; 5) mežs ar neidentificējamām koku sugām; 6) meža fragmenti/elementi cita tipa ainavā. Slapjie meži tika izslēgti no analīzes ḷoti nelielās pārstāvniecības dēḷ. Lai identificētu nozīmīgākās meža ainavas, tika veikta vienkārša statistiskā analīze.

Lai novērtētu, vai mežainuma izmaiṇām valstī ir bijusi ietekme uz mākslinieku izvēli atainot meža ekosistēmas savos darbos, salīdzinājām pieejamos datus par mežainumu ${ }^{9}$ ar gleznu skaitu, kurās parādīti dažādu veidu meži (izmantojot vidējos rādītājus pa desmitgadēm). Šajā gadījumā analīzē netika iekḷautas gleznas, kurās attēloti tikai meža fragmenti vai elementi; izmantojām tikai tos darbus, kur mežs ainavā dominē. Pilna informācija par mežainumu un atbilstošo gleznu skaitu bija

\footnotetext{
9 Kronītis 1965.
} 


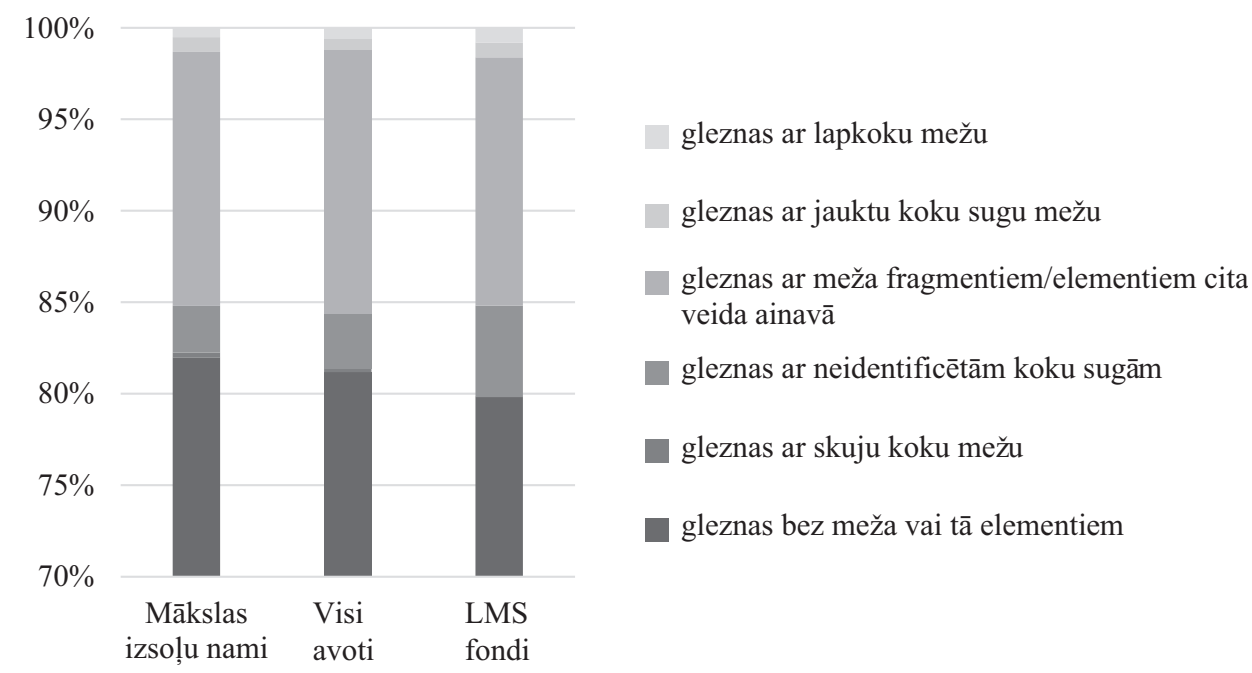

1. attēls. Meža ekosistēmu un meža elementu attēlošanas biežums analizētajās gleznās (Pauliņa, Lībiete 2019)

pieejama laika posmam no 20. gs. 20. līdz 90. gadiem (ieskaitot), un šis laika ietvars arī tika izmantots analīzē.

Lai novērtētu, vai un kā dominējošā ainava, kas raksturīga kāda mākslinieka dzīves un darba vietai, ir ietekmējusi viņa radošās izpausmes, tika analizēta pieejamā informācija no tādu mākslinieku biogrāfijām, kuru darbi bija iekḷauti pētāmajās datu kopās. Izmantojām dalījumu šādos apgabalos: 1) Rīga; 2) Pierīga; 3) Latgale; 4) Zemgale; 5) Vidzeme; 6) Kurzeme; 7) nezināms.

\section{Rezultāti un diskusija}

Gleznas, kurās atainots mežs vai meža elementi, veidoja caurmērā $19 \%$ no visiem analizētajiem mākslinieku darbiem (pilnā datu kopa, darbi no 20. un 21. gadsimta); abās atsevišķajās datu kopās šis īpatsvars bija visai līdzīgs (18\% gleznām no izsoḷu namiem un 20\% gleznām no Latvijas Mākslinieku savienības fondiem). Arī gleznu īpatsvars ar meža fragmentiem vai elementiem (no gleznām, kur vispār bija attēlots mežs) abās datu kopās bija līdzīgs: vidēji 76\%. Nākamā biežāk attēlotā kategorija ir mežs ar neidentificējamām koku sugām, tam seko jauktu koku sugu mežs, lapkoku mežs un skujkoku mežs (attiecīgi 16\%,
$4 \%, 3 \%$ un $1 \%$ no visām gleznām, kur attēlots mežs) (1. attēls).

Dažādo meža ainavu attēlojums gleznās atspoguḷo gan Latvijai raksturīgo meža ainavu, ko veido relatīvi mazas audzes (vidējais nogabala lielums Latvijā ir 1,26 $\pm 1,46 \mathrm{ha}^{10}$ ) ar skujkoku un lapkoku mozaīkveida rakstu, gan arī mākslinieku estētisko uztveri, biežāk izvēloties atainot krāsainākos un neregulārākos jauktos mežus vai lapkoku mežus, nevis salīdzinoši vienveidīgākos un homogēnākos skujkoku mežus.

Meža fragmenti vai meža elementi bieži tiek izmantoti par fonu vai akcentu kompozīcijas izlīdzināšanai cita veida ainavās.

Latvijā 20. gadsimta gaitā mežainums pakāpeniski pieauga, palielinoties no $26 \%$ 1920. gadā līdz 44\% 1990. gadā. Zemes īpašumtiesību un zemes izmantošanas struktūra radikāli izmainījās pēc Pirmā pasaules kara un valsts neatkarības pasludināšanas; meži pārsvarā nonāca valsts īpašumā, bet lauksaimniecības zemes - privātīpašumā. 20. gs. 30. gados valstiskā mērogā tika veicināta lauksaimniecības zemju apmežošana atsevišķos reǵionos gan tāpēc, ka lauksaimniekiem bija

\footnotetext{
10 Meža valsts reǵistra dati. Sk. Meža statistikas CD 2018.
} 


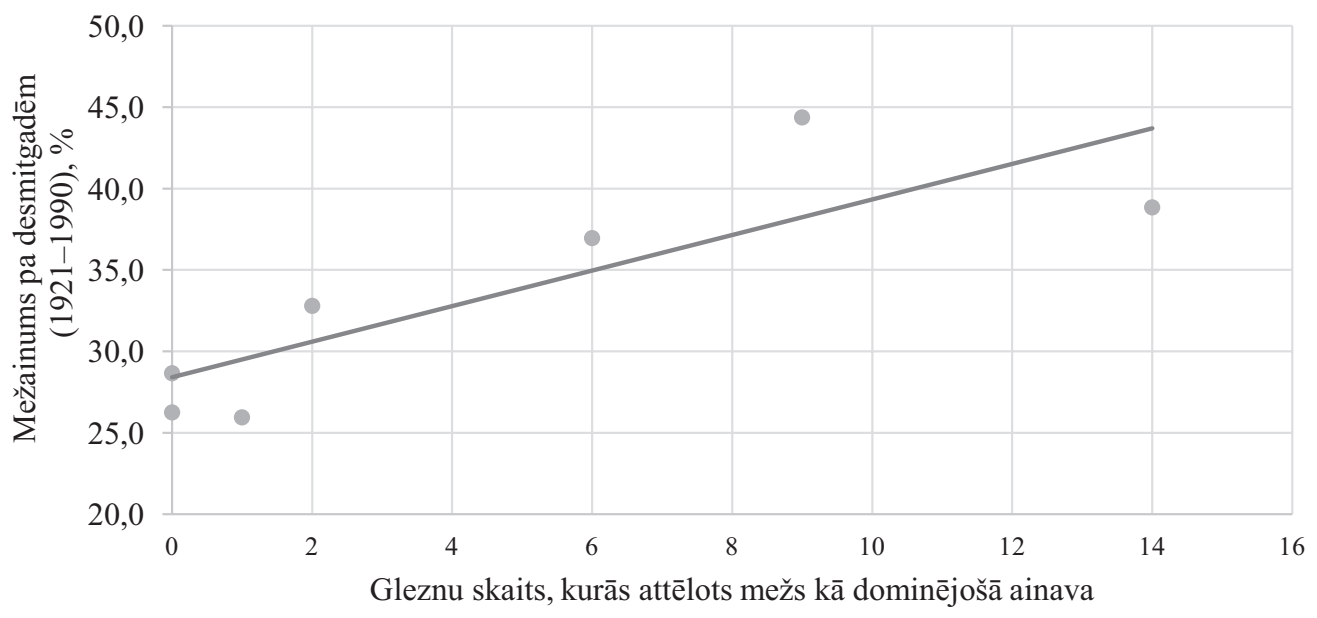

2. attēls. Korelācija starp mežainumu (\%) un meža attēlojuma biežumu gleznās (Pauliņa, Lībiete 2019)

Tabula. Analizēto mākslas darbu autoru dzimšanas vietas $(\boldsymbol{n}=\mathbf{1 7 5})$

(Latvijas Mākslinieku savienības datu kopa)

\begin{tabular}{lccccccc}
\hline & Rīga & Pierīga & Latgale & Zemgale & Vidzeme & Kurzeme & Nav zināms \\
\hline Mākslinieku skaits & 51 & 14 & 12 & 18 & 36 & 22 & 22 \\
\hline \% no kopējā & 29,1 & 8,0 & 6,9 & 10,3 & 20,6 & 12,6 & 12,6 \\
\hline
\end{tabular}

vajadzīgi koksnes resursi, gan arī tāpēc, ka tika uzskatīts: meža platību palielināšanās palielinās eksporta vērtību ${ }^{11}$. Konstatējām pozitīvu korelāciju pa desmitgadēm starp mežainumu Latvijā un gleznu skaitu, kurās attēlots mežs (2. attēls). Šie rezultāti gan ir vērtējami piesardz̄igi, tāpēc ka, visticamāk, arī citi faktori bez mežainuma palielināšanās ir ietekmējuši šo procesu, piem., pieaugošais mākslinieku skaits. Tomēr šo var uzskatīt par pietiekami nozīmīgu tendenci un iegūtie rezultāti netieši apstiprina meža ekosistēmu kā iedvesmas avota nozīmi mākslā.

Vairāk nekā viena trešā daḷa mākslinieku (65), kuru darbi tika analizēti, bija dzimuši Rīgā vai tās apkārtnē. No pārējiem apgabaliem visvairāk pārstāvēta bija Vidzeme (tabula). Kaut arī dạ̧a mākslinieku dzimuši pilsētās, tomēr Latvijas lauku apvidos pilsētu tuvumā parasti atrodas arī meži un varam pieņemt, ka lielākajai dalai mākslinieku bijusi cieša saikne ar dabiskajām ekosistēmām. Lai gan 20. gadsimtā kaut vai tikai sarežğìtās politiskās situācijas dēl vien mākslinieku dzīvesvietas bijušas visai main̄̄gas neatkarīgi no viṇu dzimšanas vietām, varam pieņemt (un to apliecina arī mākslinieku biogrāfijas), ka daudzi mākslinieki lielu daḷu dzīves pavadījuši savā dzimtajā pusē. No iegūtajiem datiem nav iespējams secināt, vai mākslinieku radošo darbību vairāk ietekmējusi pilsētas vai lauku vide, tomēr domājams, ka liela dala no viniem daudz laika pavadījuši dabā, gleznojot plenēros.

3.-6. attēlā redzamas lauku ainavas, ko gleznojuši četri Latvijas mākslinieki, kas dzimuši atškirīgos Latvijas apgabalos, un vinu mākslas darbos iespējams saskatīt dažas raksturīgas regiionālas savdabības.

${ }^{11}$ Bells, Nikodemus 2000. 


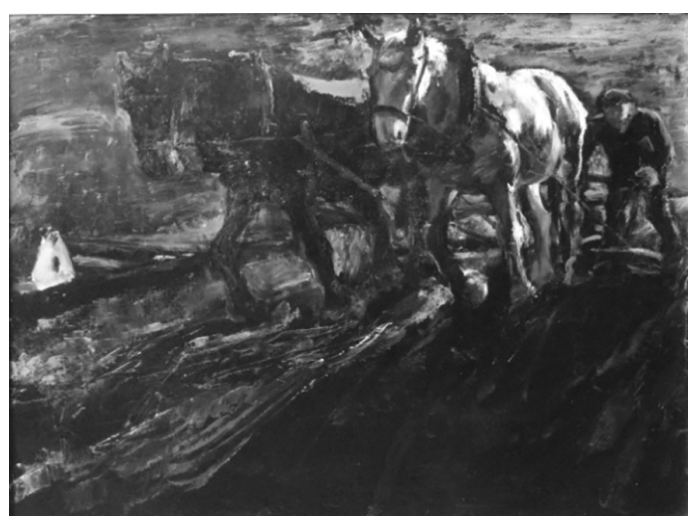

3. attēls. Pirms 20 gadiem (1965). Ģederts Eliass, Zemgale

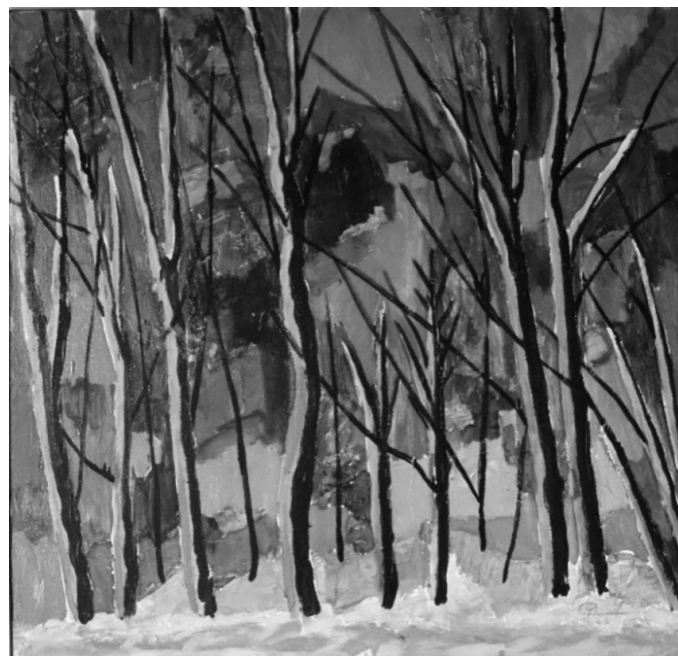

5. attēls. Rudens (1976). Rūdolfs Pinnis, Vidzeme

Ainavu attēlojuma piemēri (3.-6. attēls) 20. gadsimta Latvijas mākslinieku gleznās ${ }^{12}$

Pirmo ainavu gleznojis Gederts Eliass (1887-1975), kurš dzimis Platones novadā, Jelgavas apkārtnē, Zemgalē. Reālisma pārstāvis, strādājis dažādos žanros. Piemērs rāda lauksaimnieku, kas apstrādā zemi Zemgalei tipiskā lauku ainavā. Zemgale atrodas Latvijas dienvidu daḷā, un gan tagad, gan vēsturiski tai

${ }_{12}$ Pauliņa, Lỉbiete 2019.

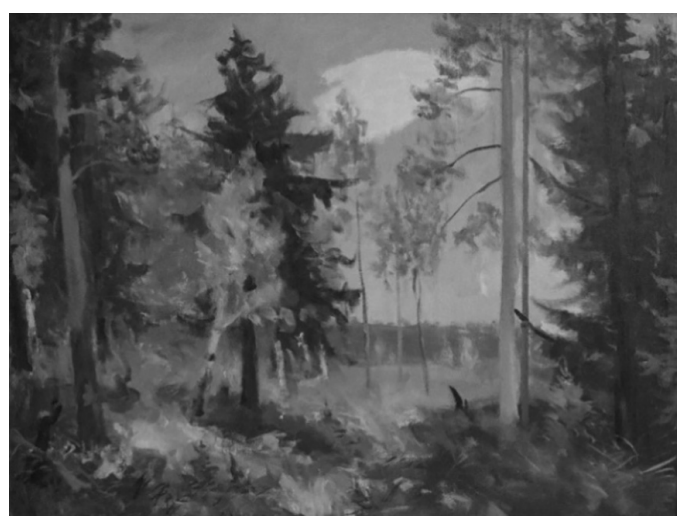

4. attēls. Saulaina diena mežă (1962). Kārlis Miesnieks, Vidzeme

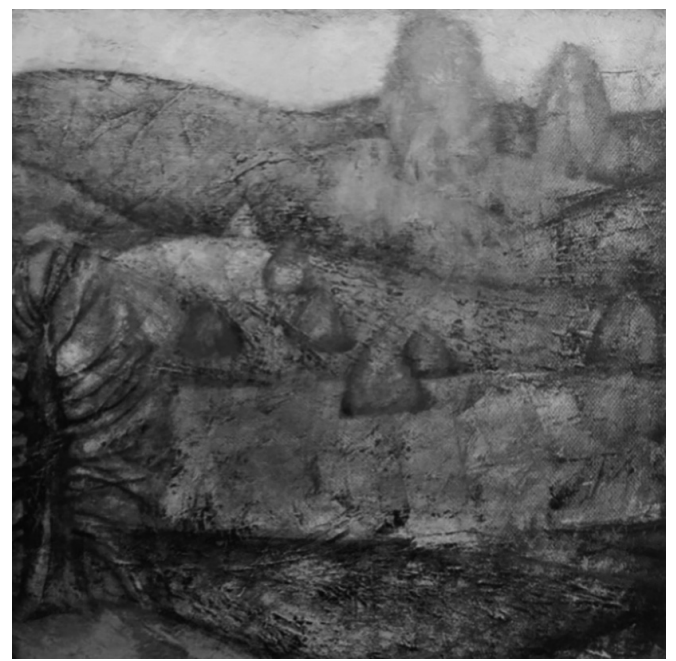

6. attēls. Rudens (1968). Jāzeps Pīgoznis, Latgale

raksturīgs augstākais lauksaimniecības zemju īpatsvars un salīdzinoši mazs mežainums.

Otrās gleznas autors Kārlis Miesnieks (1887-1977) dzimis Jaunpiebalgas novadā, Vidzemē. Reālisma pārstāvis, gleznojis klusās dabas, ainavas, portretus. Mākslinieka dzimtajam novadam raksturīgas lielas mežu platības, un gleznotā ainava var tikt uzskatīta par regionam visai tipisku.

Trešā glezna ir Rūdolfa Piņņa darbs (1902-1992). Viņš dzimis Madonā, Vidzemē. Viens no paz̄̄stamākajiem un populārākajiem latviešu gleznotājiem, fovisma stila pārstāvis Latvijas glezniecībā. Viṇa darbiem raksturīga 


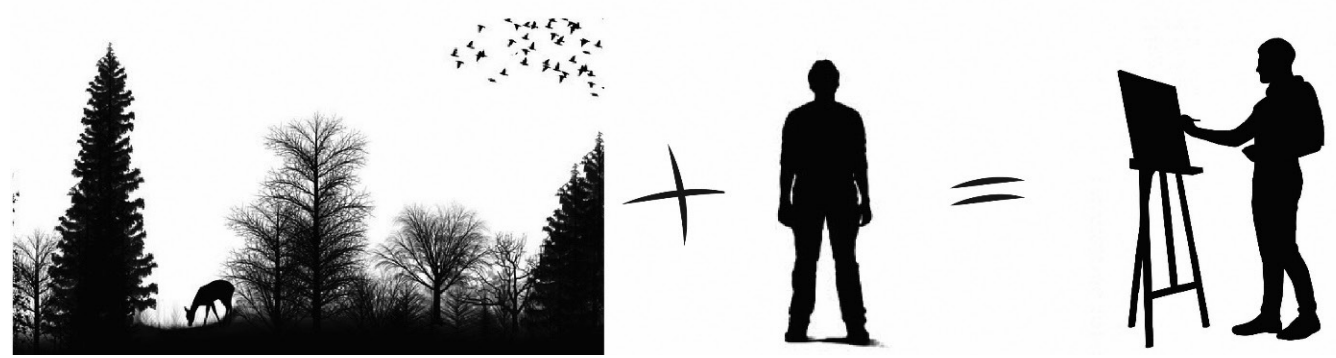

7. attēls. Dabiskās ekosistēmas kā iedvesma radošumam

(Pauliņa, Lībiete 2019)

dinamika un ekspresija, piesātinātas krāsas. Daudzās Rūdolfa Piṇna gleznās attēlots mežs, un, kaut arī izmantotā stila dēl lielākoties nav iespējams izšķirt konkrētas sugas vai meža tipus, varam uzskatīt, ka mākslinieka dz̄ives un darba vieta ir ietekmējusi viṇa radošās izpausmes.

Ceturtās gleznas autors Jāzeps Pīgoznis (1934-2014) dzimis Silmalas pagastā, Latgalē. Daudzpusīgs mākslinieks. Ezeri, pakalni un nelielas meža platības ir raksturīgas Latgales reǵionam un nolasāmas arī šajā piemērā.

Protams, aplūkotie piemēri analizēti, lielā mērā balstoties uz pieņēmumiem. Mākslinieku biogrāfijas bieži ir nepiln̄̄gas 20. gadsimta sarežğîtās politiskās un ekonomiskās situācijas dēḷ. Katra mākslinieka personiskais stils ir ietekmējis dabas atveidojumu, un daudzos gadījumos nebija iespējams detalizētāk analizēt attēloto meža tipu. Tomēr šie piemēri norāda uz zināmām tendencēm un sniedz ieskatu, kā ekosistēmas nodrošina kultūras pakalpojumus, šajā gadījumā - iedvesmu mākslas darbu radīšanai. Pētījuma rezultāti gan tieši, gan netieši apstiprina, ka reǵionā dominējošās ekosistēmas, šajā gadījumā - meži, ir l̦oti nozīmīgi attiecīgā apgabala iedzīvotāju kultūras identitātes veidošanā, ieskaitot radošās izteiksmes formu (7. attēls). Pētījums norāda arī, ka mākslas darbi var tikt izmantoti, lai labāk izprastu un ilustrētu atsevišķu ekosistēmu tipu un to elementu nozīmi radošuma iedvesmošanā un uzturēšanā. Ar mākslas darbiem mākslinieki atklāj sabiedrībai savu pasaules un vērtîbu uztveres modeli, tādējādi bagātinot arī citu cilvēku kultūras pieredzi.

Jāsaprot, ka kultūra ir sarežǵīta parādība, kas ietver gan materiālus, gan nemateriālus aspektus, un pēdējie visbiežāk tiek piedzīvoti un izbaudīti, nevis aprakstīti vai novērtēti ${ }^{13}$. Tomēr mēginājumi kvantificēt nemateriālos pakalpojumus ir svarīgi, jo tādējādi tiek radīti rīki, kas l,auj iekḷaut ekosistēmu apsaimniekošanā papildu aspektus un ir l,oti vajadzīgi ekosistēmu sniegto pakalpojumu daudzfunkcionalitātes izpratnei. Tā pētījumā par ekosistēmu kā iedvesmas avota nozīmi populārajā mūzikā secināts, ka ekosistēmas sniegušas 0,6 miljardu dolāru ieguldījumu mūzikas industrijā desmit gadu laikā, un interesanti, ka viena no nozīmīgākajām ekosistēmām šajā aspektā bijuši tropu meži ${ }^{14}$.

Pētījumi, kuros analizēts kāda viena ekosistēmas tipa atainojums, lai kvantitatīvi novērtētu šis ekosistēmas nozīmi kultūras (iedvesmas) ekosistēmu pakalpojumu nodrošināšanā, ir reti sastopami, un, saskan̄ā ar autorēm pieejamo informāciju, šeit aprakstītais ir pirmais šāda veida pētījums Baltijas valstīs. Tas var tikt paplašināts un detalizēts, iekḷaujot vēl citus radošuma aspektus, ko ietekmē ainava un ekosistēmas, kā arī, piem., iekḷaujot mākslas tirgus analīzi, tādējādi cenšoties piešksirt pētîtajam ekosistēmu pakalpojumam naudas vērtību.

\section{Secinājumi}

Relatīvi augstais gleznu ippatsvars ar meža ainavas vai meža elementu atainojumu (gandrīz trešā daḷa no visām analizētajām gleznām) apliecina meža ekosistēmas kultūras

\footnotetext{
13 Satterfield et al. 2013.

14 Coscieme 2015.
} 
pakalpojuma (šajā gadījumā - iedvesmas mākslas darbu radīšanai) nozīmi Latvijā.

Visbiežāk sastopamais meža ekosistēmas attēlojums ainavā izpildīts meža elementu vai meža fragmentu veidā, lai līdzsvarotu darba kompozīciju un akcentētu galveno tēmu. Nākamā biežāk sastopamā grupa ir meži ar neidentificējamām koku sugām un jaukti meži.

Vērojams, ka, pieaugot meža īpatsvaram Latvijas ainavā, pieaug gleznu skaits, kurās attēlots mežs.
Ainavu īpatnības, kas raksturīgas Latvijas ainavu gleznotāju dzimšanas un darba vietām, novērojamas viņu radošajās izpausmēs gleznās.

Šis pētījums daḹeji īstenots Latvijas Valsts mežzinātnes institūta Silava un AS Latvijas valsts meži sadarbības pētījumu programmas Nr. 5-5.5 $006 \quad 101 \quad 16 \quad 6 \quad$ Mežsaimniecības ietekme uz meža un saistīto ekosistēmu pakalpojumiem ietvaros.

\section{VĒRES}

Apvienoto Nāciju Organizācijas Meža izmantošanas principi (1992) Report of the United Nations Conference on Environment and Development, Annex III: Non-legally binding authoritative statement of principles for a global consensus on the management, conservation and sustainable development of all types of forests. Rio de Janeiro (03.-14.06.1992.).

Bells, S.; Nikodemus, O. (2000) Rokasgrāmata meža ainavas plānošanai un dizainam. Rīga : McĀbols. Coscieme, L. (2015) Cultural ecosystem services: The inspirational value of ecosystems in popular music. Ecosystem Services, 16, 121-124.

de Groot, R.; Ramakrishnan, P. S.; van de Berg A.; Kulenthran, T.; Muller, S.; Pitt, D.; Wascher, D.; Wijesuriya, G.; Amelung, B.; Eliezer, N.; Gopal, A. R.; Rössler, M. (2005) Cultural and Amenity Services. Ecosystems and Human Well-being: Current State and Trends, 1. Washington, D. C. : Island Press, 455-476.

Haines-Young, R.; Potschin, M. B. (2018) Common International Classification of Ecosystem Services (CICES) V5.1 and Guidance on the Application of the Revised Structure. Pieejams: www.cices.eu.

Kronītis, J. (1965) Latvijas mežu apsaimniekošana. Rīga : Liesma.

Latvijas Republikas Meža likums (2000).

Latvijas Republikas Zemkopības ministrija (2019) Meža un meža zemes platības Latvijā. Pieejams: https:// www.zm.gov.lv/mezi/statiskas-lapas/nozares-informacija/meza-resursi? nid=1086\#jump (26.02.2019.).

Meža statistikas CD (2018) Pieejams: http://www.vmd.gov.lv/valsts-meza-dienests/statiskas-lapas/publikacijas-un-statistika/meza-statistikas-cd?nid=1809\#jump (05.01.2019.).

Millennium Ecosystem Assessment: Ecosystems and Human Well-being: Synthesis (2005) Washington, D. C. : Island Press.

Paulina, I.; Lībiete, Z. (2019) Analysis of landscape paintings to highlight the importance of forest ecosystems in Latvia. Proceedings of the 25th Intarnational Scientific Conference Research for Rural Development 2019, Jelgava, Latvia, May 15-17, 2019.

Satterfield, T.; Gregory, R.; Klain, S.; Roberts, M.; Chan, K. M. (2013) Culture, intangibles and metrics in environmental management. Journal of Environmental Management, 117, 103-114.

Shvidenko, A.; Barber, C. V.; Persson, R.; Gonzalez, P.; Hassan, R.; Lakyda, P.; McCallum, I.; Nilsson, S.; Pulhin, J.; van Rosenburg, B.; Scholes, B. (2005) Forest and Woodland Systems: Ecosystems and Human Well-being: Current State and Trends, 1. Washington, D. C. : Island Press, 585-621.

TEEB (2010) The Economics of Ecosystems and Biodiversity: Mainstreaming the Economics of Nature: A synthesis of the approach, conclusions and recommendations of TEEB.

The Common International Classification of Ecosystem Services (2019) Pieejams: https://cices.eu/. 